\title{
ANALISIS MULTIPLE INTELLIGENCES TERHADAP KECENDERUNGAN MINAT MAHASISWA PASCA STUDI DENGAN METODE HONGARIAN
}

\author{
Abdul Halim Fathani ${ }^{1}$, Sikky El Walida ${ }^{2}$ \\ ${ }^{1,2}$ Program Studi Pendidikan Matematika Universitas Islam Malang \\ 1athani@unisma,ac.id, ${ }^{2}$ sikkywalida@yahoo.co.id
}

\begin{abstract}
Abstrak
Perguruan tinggi harus mereformulasi visi, misi dan tradisi yang berorientasi pada efisiensi dan profesionalisme guna membangun dan menghasilkan lulusan yang kompetitif. Universitas Islam Malang, termasuk di dalamnya Program Studi Pendidikan Matematika merupakan salah satu lembaga pendidikan yang turut andil dalam menyiapkan generasi unggul yang mampu bersaing. Setiap orang mempunyai cara yang unik untuk menyelesaikan persoalan yang dihadapinya. Mahasiswa termasuk individu unik yang mempunyai eksistensi dan memiliki jiwa sendiri, serta mempunyai hak untuk tumbuh dan berkembang secara optimal sesuai dengan iramanya masing-masing yang khas yang dinamakan potensi kecerdasan. Program Studi Pendidikan Matematika Universitas Islam Malang memiliki tantangan untuk bisa menghasilkan tenaga terampil yang dibutuhkan oleh lapangan kerja dan menghasilkan inovasi yang bisa memberikan manfaat ekonomis secara langsung bagi masyarakat. Tentu, hal ini akan sangat dipengaruhi oleh faktor multiple intelligences yang menjadi kecenderungan setiap individu. Dalam tulisan ini, peneliti melakukan kajian multiple intelligences terhadap kecenderungan minat mahasiswa pasca studi dengan analisis Metode Hongarian.

Kata Kunci: Multiple Intelligences, Minat Mahasiswa, Pasca Studi, Metode Hongarian
\end{abstract}

\section{PENDAHULUAN}

Pada tahun 2015 Indonesia menghadapi implementasi Masyarakat Ekonomi Asean (MEA). Tantangan dan peluang di MEA akan menguji kesiapan daya saing dan produktivitas bangsa Indonesia. Pendidikan Tinggi di Indonesia perlu menyiapkan generasi muda yang profesional dan berdaya saing agar dapat menjadikan bangsa Indonesia pemenang dalam persiapan persaingan ekonomi bebas didalam negeri ini. (Anonim, 2015). Kondisi realita masyarakat yang jauh berbeda dengan kehidupan sewaktu di kampus membuat lembaga pendidikan harus mampu menjadikan lulusannya mampu bersaing dan mampu menawarkan mutu serta pelayanan yang bagus.

Dalam rangka mengantisipasi tuntutan dan tantangan tersebut, Hamid menawarkan kunci untuk memenangkan persaingan, yakni: PT harus selalu mengorientasikan diri pada peningkatan kualitas kelembagaan dan sumber daya manusia (SDM) sehingga bisa melahirkan karya-karya inventif-inovatif yang bermanfaat bagi masyarakat, terus melakukan 
pengembangan ilmu pengetahuan, serta menghasilkan lulusan yang berdaya saing tinggi (Hamid, 2015). Perguruan tinggi harus mampu melayani berbagai kebutuhan masyarakat secara kompetitif. Nilai kompetitif perguruan tinggi sesungguhnya terletak pada kemampuannya melayani masyarakat dengan kualifikasi kemampuan dan profesionalisme yang tinggi.

Dalam menghadapi tuntutan kebutuhan masyarakat menyongsong implementasi Masyarakat Ekonomi Asean (MEA), kurikulum di Universitas Islam Malang, termasuk di Program Studi Pendidikan Matematika, saat ini telah mengalami perkembangan dengan mengikuti kebijakan pemerintah, yakni kurikulum berbasis kompetensi (KBK), yang pada hakikatnya adalah memandirikan atau memberdayakan Institusi dalam mengembangkan kompetensi yang sesuai dengan kondisi lingkungannya. Di sisi lain, untuk menjawab tantangan globalisasi berdasarkan Peraturan Presiden RI Nomor 8 Tahun 2012, kurikulum harus mengacu pada standar Kerangka Kualifikasi Nasional Indonesia (KKNI) yang merupakan kerangka penjenjangan kualifikasi kompetensi yang dapat menyandingkan, menyetarakan, dan mengintegrasikan antara bidang pendidikan dan bidang pelatihan kerja serta pengalaman kerja dalam rangka pemberian pengakuan kompetensi kerja sesuai dengan struktur pekerjaan di berbagai sektor.

Kurikulum KBK selaras KKNI yang dikembangkan Program Studi Pendidikan Matematika Fakultas Keguruan dan Ilmu Pendidikan Universitas Islam Malang ini dapat menjadi pijakan dalam pelaksanaan kegiatan Tri Dharma Perguruan Tinggi untuk mengantarkan lulusan yang unggul dalam bidang profesi utama sebagai Pendidik Matematika Sekolah Menengah. Selain itu, dengan Kurikulum KBK selaras KKNI ini, Program Studi Pendidikan Matematika Universitas Islam Malang juga ingin mengantarkan lulusan untuk mampu di bidang profesi alternatif lainnya, meliputi: Manajer Sekolah, Pendidik Sekolah Berbasis Islam ASWAJA, dan Pengembang Media Pembelajaran Matematika. (Pedoman Pendidikan Prodi Pendidikan Matematika Unisma, 2014).

Merespons hal di atas, maka pelbagai program peningkatan SDM lulusan perguruan tinggi harus mendapatkan prioritas, salah satunya dengan mengantarkan lulusan (minimal) sesuai dengan profil khas yang dimiliki Universitas Islam Malang. Menurut Wuryandani (Wuryandani, 2014), usaha peningkatan kualitas SDM bisa ditempuh dengan upaya sinergi antara pemerintah, pelaku usaha, dan akademisi untuk menetapkan standar kompetensi profesionalisme di masing-masing sektor. Upaya peningkatan kualitas SDM untuk bersaing dalam menghadapi MEA 2015 harus segera dilaksanakan dalam rangka mencapai kemajuan dan mengejar ketertinggalannya dari negara-negara lain.

Terkait dengan profil lulusan, tentu tidak bisa dilepaskan dari riwayat mahasiswa selama mengikuti proses pendidikan di kampus. Mahasiswa, pada dasarnya merupakan individu yang unik. Sesungguhnya setiap mahasiswa itu dilahirkan dalam keadaan cerdas dengan membawa potensi dan keunikan masing-masing yang memungkinkan mereka untuk menjadi sang juara. Gardner (2010) menyatakan terdapat delapan kecerdasan pada manusia, yaitu kecerdasan linguistik, kecerdasan matematik, kecerdasan spasial, kecerdasan musikal, 
kecerdasan kinestetik, kecerdasan interpersonal, kecerdasan intrapersonal, dan kecerdasan naturalis.

Berpijak pada keunikan kecerdasan yang dimiliki setiap individu di atas, sangat dimungkinkan setiap individu akan memiliki kecenderungan minat yang tidak sama. Memang, merujuk pada profil lulusan yang ditetapkan Program Studi Pendidikan Matematika Universitas Islam Malang, maka lulusannya diharapkan dapat memainkan peran sebagaimana profesi pada profil lulusan yang dicita-citakan. Pada faktanya, seiring dengan persaingan dalam menghadapi MEA 2015 akan terbuka peluang mahasiswa bisa berpofesi di luar yang ditetapkan tersebut.

Program Studi Pendidikan Matematika Universitas Islam Malang memiliki tantangan untuk bisa menghasilkan tenaga terampil yang dibutuhkan oleh lapangan kerja dan menghasilkan inovasi yang bisa memberikan manfaat ekonomis secara langsung bagi masyarakat. Tentu, hal ini akan sangat dipengaruhi oleh faktor multiple intelligences yang menjadi kecenderungan setiap individu. Oleh karena itu, peneliti tertarik melakukan penelitian analisis multiple intelligences terhadap kecenderungan minat mahasiswa pasca studi (ketika lulus kuliah) dengan Metode Hongarian.

\section{METODE}

Pendekatan penelitian yang digunakan adalah deskriptif kualitatif. Bogdan dan Biklen (Bogdan dan Biklen, 1998) menyatakan bahwa metode penelitian kualitatif adalah sebagai prosedur penelitian yang menghasilkan data deskriptif berupa kata-kata tertulis atau lisan dari orang-orang dan perilaku yang diamati. Sugiyono (Sugiyono, 2007) menambahkan bahwa pendekatan kualitatif digunakan untuk mendapatkan data yang mendalam, suatu data yang mengandung makna. Makna adalah data yang sebenarnya, data yang pasti merupakan suatu nilai di balik data yang tampak.

Beberapa pendapat hasil wawancara dideskripsikan yang kemudian diinterpretasikan secara kualitatif. Data yang diperoleh dari hasil kuesioner mahasiswa yang bersifat kuantitatif juga diinterpretasikan secara kualitatif. Hal ini dimaksudkan untuk memberikan informasi dan wawasan serta masukan tentang kecenderungan minat mahasiswa pasca studi yang ditinjau dari tingkat multiple intelligences dan kemudian dianalisis dengan metode hongarian

Sedangkan jenis penelitian yang digunakan adalah studi kasus. Menurut Danim (Danim, 2008) penelitian studi kasus merupakan studi mendalam mengenai unit sosial tertentu, yang hasil penelitian itu memberi gambaran luas dan mendalam mengenai unit sosial tertentu. Subjek yang diteliti relatif terbatas, tetapi variabel-variabel dan fokus yang diteliti sangat luas dimensinya. Dalam penelitian ini, kasus yang diamati adalah kecenderungan minat pasca studi yang dialami mahasiswa Program Studi Pendidikan Matematika Universitas Islam Malang.

Data dalam penelitian ini berupa data kualitatif dan kuantitatif yang kemudian diinterpretasikan secara kualitatif. Data yang dikumpulkan untuk kepentingan penelitian ini adalah mengenai kecenderungan minat mahasiswa Program Studi Pendidikan Matematika 
pasca studi yang ditinjau berdasarkan tingkat multiple intelligences mahasiswa. Dalam penelitian ini, data yang diamati adalah difokuskan pada hubungan tingkat multiple intelligences mahasiswa dengan kecenderungan minat mahasiswa pasca studi. Adapun Instrumen penelitian ini adalah peneliti sendiri yang dipandu dengan instrumen Multiple Intelligences Research (MIR), kuesioner kecenderungan minat mahasiswa pasca studi.

Dalam pengumpulan data penelitian menggunakan beberapa metode, seperti dengan menggunakan pertanyaan terstruktur, observasi, kuesioner, wawancara, rekaman dengan video, pelacakan dokumen, dan studi kasus. Sesuai dengan sumber data di atas, maka agar data yang dikumpulkan dapat diolah dan digunakan untuk menjawab rumusan permasalahan dalam penelitian ini, peneliti menggunakan teknik wawancara mendalam, observasi partisipan, dan studi dokumentasi. Setelah data dikumpulkan dengan menggunakan metode observasi, kuesioner, studi dokumentasi, dan wawancara, selanjutnya dilakukan triangulasi data, yakni menggabungkan dari berbagai teknik pengumpulan data dan sumber data yang telah ada untuk mengecek kredibilitas data.

\section{HASIL DAN PEMBAHASAN}

Setelah dilakukan proses analisis data dengan menggunakan metode Hongarian sampai diperoleh matriks yang telah memenuhi untuk dilakukan optimalisasi, selanjutnya akan dilakukan identifikasi untuk mencari variasi penetapan optimal yang mungkin untuk dilakukan. Berdasarkan analisis metode hongarian, dimungkinkan ada 3 (tiga) alternatif untuk penetapan optimal sebagai berikut.

\section{Alternatif Penetapan Optimal Pertama}

Di bawah ini akan dipaparkaan matriks yang merupakan hasil dari alternatif penetapan optimal yang pertama.

\section{Tabel 2. Matriks Penetapan Optimal (Alternatif 1)}

\begin{tabular}{|c|c|c|c|c|c|c|c|c|}
\hline M & है & 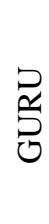 & 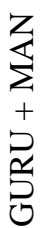 & 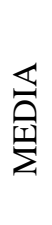 & $\stackrel{\infty}{\cdots}$ & 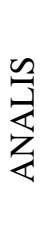 & $\begin{array}{l}\text { 茂 } \\
\text { z } \\
\text { Z }\end{array}$ & 売 \\
\hline LINGUISTIK & $\mathbf{0}$ & $\mathbf{0}$ & $\mathbf{0}$ & $\mathbf{0}$ & $\mathbf{0}$ & $\mathbf{0}$ & $\mathbf{0}$ & $\mathbf{0}$ \\
\hline MATEMATIK & 1 & $\mathbf{0}$ & 4 & 2 & 4 & 3 & 5 & 5 \\
\hline MUSIK & 2 & $\mathbf{0}$ & 1 & $\mathbf{0}$ & 2 & 2 & 3 & $\mathbf{0}$ \\
\hline SPASIAL & 2 & 1 & $\mathbf{0}$ & 1 & 2 & 3 & 3 & 3 \\
\hline INTERPERSONAL & $\mathbf{1}$ & 0 & 0 & 1 & 0 & 1 & 2 & 1 \\
\hline
\end{tabular}




\begin{tabular}{|l|c|c|c|c|c|c|c|c|}
\cline { 2 - 9 } INTRAPERSONAL & $\mathbf{1}$ & $\mathbf{0}$ & $\mathbf{2}$ & $\mathbf{2}$ & $\mathbf{2}$ & $\mathbf{0}$ & $\mathbf{3}$ & $\mathbf{1}$ \\
\hline KINESTETIK & $\mathbf{1}$ & $\mathbf{1}$ & $\mathbf{3}$ & $\mathbf{2}$ & $\mathbf{0}$ & $\mathbf{1}$ & $\mathbf{0}$ & $\mathbf{0}$ \\
\hline NATURALIS & $\mathbf{0}$ & $\mathbf{1}$ & $\mathbf{2}$ & $\mathbf{1}$ & $\mathbf{2}$ & $\mathbf{2}$ & $\mathbf{2}$ & $\mathbf{2}$ \\
\hline
\end{tabular}

Penetapan optimal yang ditunjukkan dalam matriks Tabel 4.11 di atas, diperoleh pasangan kaitan antara kecenderungan multiple intelligences dan minat pasca studi mahasiswa, dengan rincian sebagai berikut:
Linguistik $\rightarrow$ Media
$($ Susunan skala $=1)$
Matematik $\rightarrow$ Guru
$($ Susunan skala $=5)$
Musik $\rightarrow$ Lainnya
$($ Susunan skala $=2)$
Spasial $\rightarrow$ Guru \& Manajer
$($ Susunan skala $=4)$
Interpersonal $\rightarrow$ LBB
$($ Susunan skala $=2)$
Intrapersonal $\rightarrow$ Analis
$($ Susunan skala $=2)$
Kinestetik $\rightarrow$ Non Matematik $\quad($ Susunan skala $=3$ )
Naturalis $\rightarrow$ Studi Lanjut (S2) $\quad($ Susunan skala $=4)$

Dengan demikian, maka jumlah susunan skala maksimum yang dihasilkan dalam penetapan optimal alternatif 1 adalah $1+5+2+4+2+2+3+4=23$. Untuk bilangan dalam susunan skala di atas, diperoleh dari data dari matriks awal atau data mentah yang merupakan rekap hasil pengisian kuesioner yang diedarkan kepada subjek penelitian. Data tersebut merupakan data yang terdapat dalam baris ke- $i$ dan kolom ke- $j$ dalam matriks penetapan optimal (alternatif 1), yang disesuaikan dengan data matriks awal (data mentah).

\section{Alternatif Penetapan Optimal Kedua}

Selanjutnya akan dipaparkan matriks yang merupakan hasil dari alternatif penetapan optimal yang kedua.

Tabel 3. Matriks Penetapan Optimal (Alternatif 2)

\begin{tabular}{|c|c|c|c|c|c|c|c|c|}
\hline & ๙ู & 党 & 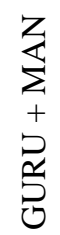 & 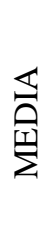 & 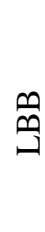 & $\begin{array}{l}\Omega \\
Z \\
z \\
z\end{array}$ & $\begin{array}{l}\text { 至 } \\
\text { Z } \\
\text { Z } \\
\text { Z }\end{array}$ & 穵 \\
\hline LINGUISTIK & $\mathbf{0}$ & $\mathbf{0}$ & $\mathbf{0}$ & $\mathbf{0}$ & $\mathbf{0}$ & $\mathbf{0}$ & $\mathbf{0}$ & $\mathbf{0}$ \\
\hline MATEMATIK & 1 & $\mathbf{0}$ & 4 & 2 & 4 & 3 & 5 & 5 \\
\hline MUSIK & 2 & $\mathbf{0}$ & 1 & $\mathbf{0}$ & 2 & 2 & 3 & $\mathbf{0}$ \\
\hline SPASIAL & 2 & 1 & $\mathbf{0}$ & $\mathbf{1}$ & 2 & 3 & 3 & 3 \\
\hline
\end{tabular}




\begin{tabular}{|l|c|c|c|c|c|c|c|c|}
\cline { 2 - 9 } INTERPERSONAL & $\mathbf{1}$ & $\mathbf{0}$ & $\mathbf{0}$ & $\mathbf{1}$ & $\mathbf{0}$ & $\mathbf{1}$ & $\mathbf{2}$ & $\mathbf{1}$ \\
\hline INTRAPERSONAL & $\mathbf{1}$ & $\mathbf{0}$ & $\mathbf{2}$ & $\mathbf{2}$ & $\mathbf{2}$ & $\mathbf{0}$ & $\mathbf{3}$ & $\mathbf{1}$ \\
\hline KINESTETIK & $\mathbf{1}$ & $\mathbf{1}$ & $\mathbf{3}$ & $\mathbf{2}$ & $\mathbf{0}$ & $\mathbf{1}$ & $\mathbf{0}$ & $\mathbf{0}$ \\
\hline NATURALIS & $\mathbf{0}$ & $\mathbf{1}$ & $\mathbf{2}$ & $\mathbf{1}$ & $\mathbf{2}$ & $\mathbf{2}$ & $\mathbf{2}$ & $\mathbf{2}$ \\
\hline
\end{tabular}

Sebagaimana yang tercantum dalam matriks Tabel 4.12 di atas, jika kita bandingkan dengan penetapan optimal sebelumnya (alternatif 1), dapat disimpulkan bahwa Penetapan optimal alternatif 2 yang ditunjukkan dalam matriks Tabel 4.12 di atas, terdapat 3 (tiga) kecerdasan yang memiliki penetapan berbeda. Selengkapnya, penetapan optimal yang ditunjukkan dalam matriks Tabel 4.12 di atas, diperoleh pasangan kaitan antara kecenderungan multiple intelligences dan minat pasca studi mahasiswa, dengan rincian sebagai berikut. Untuk kecerdasan yang memiliki penetapan berbeda, oleh peneliti ditampilkan dengan jenis font tebal.

$\begin{array}{ll}\text { Linguistik } \rightarrow \text { Non Matematik } & \text { (Susunan skala = 2) } \\ \text { Matematik } \rightarrow \text { Guru } & \text { (Susunan skala = 5) } \\ \text { Musik } \rightarrow \text { Media } & \text { (Susunan skala = 2) } \\ \text { Spasial } \rightarrow \text { Guru \& Manajer } & \text { (Susunan skala =4) } \\ \text { Interpersonal } \rightarrow \text { LBB } & \text { (Susunan skala = 2) } \\ \text { Intrapersonal } \rightarrow \text { Analis } & \text { (Susunan skala = 2) } \\ \text { Kinestetik } \rightarrow \text { Lainnya } & \text { (Susunan skala = 2) } \\ \text { Naturalis } \rightarrow \text { Studi Lanjut }(\text { S2) } & \text { (Susunan skala =4) }\end{array}$

Dengan demikian, maka jumlah susunan skala maksimum yang dihasilkan dalam penetapan alternatif 2 adalah $2+5+2+4+2+2+2+4=23$. Dalam penetapan optimal alternatif 1 ini, terdapat 3 (tiga) kecerdasan yang memiliki pasangan berbeda, yakni kecerdasan linguistik, musik, dan kinestetik. Di bawah ini akan diuraikan lebih detail, hubungan pasangan yang berbeda tersebut.

\section{Alternatif Penetapan Optimal Ketiga}

Selanjutnya akan dipaparkan matriks yang merupakan hasil dari alternatif penetapan optimal yang ketiga.

Tabel 4. Matriks Penetapan Optimal (Alternatif 3)

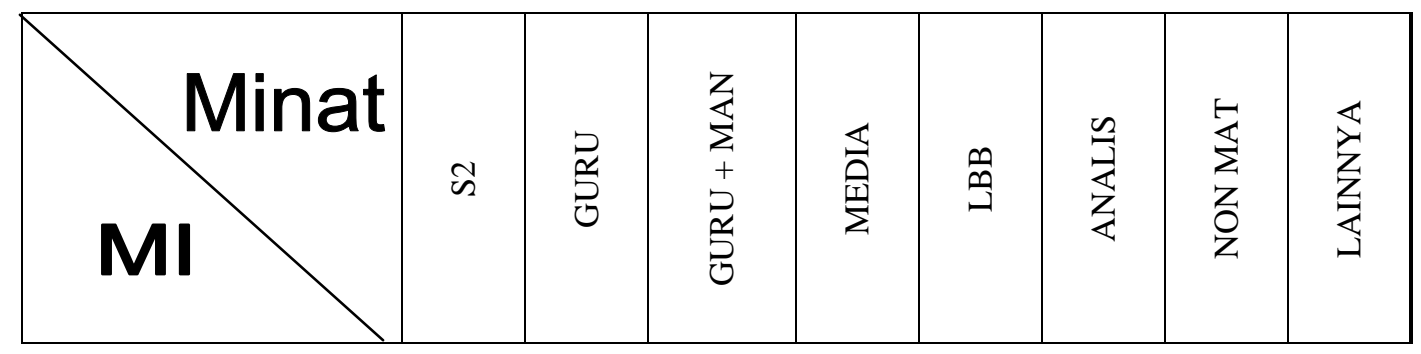




\begin{tabular}{|l|c|c|c|c|c|c|c|c|}
\cline { 2 - 9 } LINGUISTIK & $\mathbf{0}$ & $\mathbf{0}$ & $\mathbf{0}$ & $\mathbf{0}$ & $\mathbf{0}$ & $\mathbf{0}$ & $\mathbf{0}$ & $\mathbf{0}$ \\
\hline MATEMATIK & $\mathbf{1}$ & $\mathbf{0}$ & $\mathbf{4}$ & $\mathbf{2}$ & $\mathbf{4}$ & $\mathbf{3}$ & $\mathbf{5}$ & $\mathbf{5}$ \\
\hline MUSIK & $\mathbf{2}$ & $\mathbf{0}$ & $\mathbf{1}$ & $\mathbf{0}$ & $\mathbf{2}$ & $\mathbf{2}$ & $\mathbf{3}$ & $\mathbf{0}$ \\
\hline SPASIAL & $\mathbf{2}$ & $\mathbf{1}$ & $\mathbf{0}$ & $\mathbf{1}$ & $\mathbf{2}$ & $\mathbf{3}$ & $\mathbf{3}$ & $\mathbf{3}$ \\
\hline INTERPERSONAL & $\mathbf{1}$ & $\mathbf{0}$ & $\mathbf{0}$ & $\mathbf{1}$ & $\mathbf{0}$ & $\mathbf{1}$ & $\mathbf{2}$ & $\mathbf{1}$ \\
\hline INTRAPERSONAL & $\mathbf{1}$ & $\mathbf{0}$ & $\mathbf{2}$ & $\mathbf{2}$ & $\mathbf{2}$ & $\mathbf{0}$ & $\mathbf{3}$ & $\mathbf{1}$ \\
\hline KINESTETIK & $\mathbf{1}$ & $\mathbf{1}$ & $\mathbf{3}$ & $\mathbf{2}$ & $\mathbf{0}$ & $\mathbf{1}$ & $\mathbf{0}$ & $\mathbf{0}$ \\
\hline NATURALIS & $\mathbf{0}$ & $\mathbf{1}$ & $\mathbf{2}$ & $\mathbf{1}$ & $\mathbf{2}$ & $\mathbf{2}$ & $\mathbf{2}$ & $\mathbf{2}$ \\
\hline
\end{tabular}

Sebagaimana yang tercantum dalam matriks Tabel 4.13 di atas, jika kita bandingkan dengan penetapan optimal sebelumnya (alternatif 1 dan 2), dapat disimpulkan bahwa Penetapan optimal alternatif 3 yang ditunjukkan dalam matriks Tabel 4.13 di atas, terdapat 3 (tiga) kecerdasan yang memiliki penetapan berbeda. Selengkapnya, penetapan optimal yang ditunjukkan dalam matriks Tabel 4.13 di atas, diperoleh pasangan kaitan antara kecenderungan multiple intelligences dan minat pasca studi mahasiswa, dengan rincian sebagai berikut. Untuk kecerdasan yang memiliki penetapan berbeda, oleh peneliti ditampilkan dengan jenis font tebal.

\section{Linguistik $\rightarrow$ Lainnya \\ Matematik $\rightarrow$ Guru \\ Musik $\rightarrow$ Media \\ Spasial $\rightarrow$ Guru \& Manajer \\ Interpersonal $\rightarrow$ LBB \\ Intrapersonal $\rightarrow$ Analis \\ $($ Susunan skala $=2)$ \\ $($ Susunan skala $=5)$ \\ (Susunan skala $=2$ ) \\ (Susunan skala $=4$ ) \\ $($ Susunan skala $=2)$ \\ $($ Susunan skala $=2)$}

Kinestetik $\rightarrow$ Non Matematika

Naturalis $\rightarrow$ Studi Lanjut (S2)

Dengan demikian, maka jumlah susunan skala maksimum yang dihasilkan dalam penetapan alternatif 3 adalah $1+5+2+4+2+2+3+4=23$. Dalam penetapan optimal alternatif 1 ini, terdapat 3 (tiga) kecerdasan yang memiliki pasangan berbeda, yakni kecerdasan linguistik, musik, dan kinestetik. Di bawah ini akan diuraikan lebih detail, hubungan pasangan yang berbeda tersebut. 


\section{SIMPULAN}

Berdasarkan uraian di atas, dapat ditarik kesimpulan bahwa ada tiga alternatif dalam penetapan optimal. Ketiga penetapan optimal tersebut, semuanya memiliki jumlah susunan skalam maksimum yang sama, yakni berjumlah 23 (dua puluh tiga). Dilihat dari variasi pasangannya, dari kedelapan pasangan, ada 5 pasangan yang memiliki hubungan yang sama dalam semua alternatif penetapan. Sementara ada 3 hubungan yang berbeda, yakni kecerdasan linguistik, musik, dan kinestetik.

\section{DAFTAR RUJUKAN}

Anonim. 2015. Mendorong Perguruan Tinggi dalam Rangka Menghadapi MEA. http://www.ristek.go.id/index.php/module/News+News/id/15207. Diakses 15 April 2015.

Anton, Howard. 2010. Elementary Linear Algebra: Applications Version. Wiley.

Armstrong, $\quad$ T. 2010. $\quad$ Multiple Intelligences. http://www.thomasarmstrong.com/multiple_intelligences.htm. Diakses 2 April 2015.

Bogdan, R. C. \& Biklen, S. K. 1998. Qualitative Research for Education: An Introduction to Theory and Methods. Boston: Allyn \& Bacon.

Danim, S. 2008. Menjadi Peneliti Kualitatif. Bandung: Pustaka Setia.

Gardner, H. 2015. Multiple Intelligence Theory http://www.multipleintelligencetheory.co.uk/. Diakses 12 April 2015

Hamid, E.S. 2015. SDM Perguruan Tinggi Menghadapi MEA 2015. http://www.koransindo.com/read/955748/149/sdm-perguruan-tinggi-menghadapi-mea-20151422248206. Diakses 25 Februari 2015.

Howard, G. 2010. Multiple Intelligences. http://www.howardgardner.com/MI/mi.html. Diakses 2 April 2015

Jasmine, J. 2007. Professional's Guide: Teaching with Multiple Intelligences. Bandung: Nuansa.

Musrifoh, T. 2008. Cara Cerdas Belajar Sambil Bermain. Bandung: PT. Grasindo.

Nuh, M. 2013. Menyemai Kreator Peradaban (Renungan tentang Pendidikan, Agama, dan Budaya). Jakarta: Zaman.

Peraturan Presiden RI Nomor 8 Tahun 2012 tentang Kerangka Kualifikasi Nasional Indonesia (KKNI)

Prasetyo, J.R. \& Andriani Y. 2009. Multiply Your Multiple Intelligences (Melatih 8 Kecerdasan Majemuk pada Anak dan Dewasa). Yogyakarta: Andi

Rosalin, E. 2010. "Membangun Competitive Advantage Perguruan Tinggi dalam Menghadapi Tantangan dan Perubahan Abad 21". Jurnal Manajemen Pendidikan. No. 02/Tahun VI/Oktober 2010.

Sugiyono. 2007. Memahami Penelitian Kualitatif. Bandung: Alfabeta.

Susanto, H. 2005. "Penerapan Multiple Intelligences dalam Sistem Pembelajaran" dalam Jurnal Pendidikan Penabur, No. 04/Th. IV/ Juli.

Tim Penyusun. 2014. Pedoman Kurikulum Berbasis Kompetensi Selaras Kerangka Kualifikasi Nasional Indonesia Program Studi Pendidikan Matematika Universitas Islam Malang. Malang: Universitas Islam Malang.

Tim Penyusun. 2014. Pedoman Pendidikan Program Studi Pendidikan Matematika Fakultas Keguruan dan Ilmu Pendidikan Universitas Islam Malang. Malang: Unisma.

Wiryandani, D. 2014. "Peluang dan Tantangan SDM Indonesia menyongsong Era Masyarakat Ekonomi ASEAN". Info Singkat Ekonomi dan Kebijakan Publik. Vol. VI, No. 17/I/P3DI/September/2014 